\title{
Biodiversity of Dominant Cultivable Endophytic Bacteria Inhabiting Tissues of Six Different Cultivars of Maize (Zea mays L. ssp. mays) Cropped under Field Conditions
}

\author{
KATARZYNA PISARSKA* and STANISŁAW JERZY PIETR \\ Department of Plant Protection, Agriculture Microbiology Laboratory, Wrocław University \\ of Environmental and Life Science, Wrocław, Poland
}

Submitted 10 June 2014, revised 31 November 2014, accepted 19 January 2015

\begin{abstract}
Endophytic bacteria (EnB) play a crucial role in plant development. This study was an attempt to isolate and identify dominant cultivable EnB inhabiting young seedlings germinated in vitro and leaves of six maize cultivars grown under field conditions at temperate climate zone with culture-dependent approach. We isolated bacteria from field cropped maize only. Strains were identified based on 16S rRNA gene sequencing. In particular, members of Actinobacteria, Bacteroidetes, Firmicutes and $\alpha$ - and $\gamma$-Proteobacteria were found. Species of two genus Pseudomonas and Bacillus were dominant among them. Higher diversity of EnB was found in plants collected from Kobierzyce, where we identified 35 species from 16 genera with 22 species uniquely found at this field. On the contrary, from maize leaves collected at Smolice we identified 24 species representing 10 genera with 10 species uniquely isolated from this field. However, none of species was common for all cultivars at both locations. Among isolated EnB six species only, Pseudomonas clemancea, Pseudomonas fluorescens, Bacillus megaterium, Bacillus simplex, Arthrobacter nicotinovorans and Arthrobacter nitroguajacolicus, were found in aboveground parts of the same cultivar grown on both tested fields. The fact that the same cultivars, sown from the same lots of seeds, under field conditions on two different locations were colonized with noticeably different associations of cultivable EnB suggest that cultivar genotype is an important factor selecting endophytic bacteria from local agro-environment. To our knowledge this is first report about the significant variation of diversity of cultivable endophytic bacteria inhabiting aboveground parts of the same maize cultivars grown at different locations.
\end{abstract}

Ke y words: endophytic bacteria, maize, plant growth promoting bacteria

\section{Introduction}

Maize was domesticated in south-western Mexico from wild grasses (teosintes) about 9,000 years ago (Matsuoka etal., 2002) and now is one of the most important crops, cultivated across the world. In Central Europe it started to be cultivated about 200 years ago. However as a grain crop it got the wider attention of breeders and farmers in the temperate climate zone, including Poland, about 30 years ago. The relations between maize and nonpathogenic microbes, especially inhabiting maize tissues, in Central Europe's temperate climate zone are practically not described in the literature. The interrelationships between plant development and microorganisms are related to local ecological factors such as soil, climate as well as agronomic practice. The nonpathogenic relationships between plants and microbes vary from neutral to commensal or symbiotic. Harmless microbes residing in plant tissues are defined as endophytic bacteria (EnB), which form com- mensal or mutualistic relationships with theirs host (Hallman et al., 1997; Zinniel et al., 2002). Endophytes are assumed to originate from seeds, rhizosphere and/ or the aerial portions of plants from which they are isolated (Segher et al., 2004). The diversity of EnB was found to be dependent on several biotic and abiotic factors like soil type, agriculture practice, as well as plant physiology (Hallmann et al., 1997; Hardoim et al., 2008). Moreover, diverse communities of endophytic bacteria are related to plant organs from which isolation is done (Bodenhausen et al., 2013; Pal and Paul, 2013).

The study of bacterial communities associated with plants is indispensable in agricultural systems because the application of beneficial bacteria can dramatically increase production and improve plant health (Xu et al., 2013) as well as reduce agricultural production costs through more efficient use of agrochemicals.

Several papers described the endophytes of maize tissues (McInroy and Kloepper, 1995; Chelius and Triplett, 2001; Zinniel et al., 2002) but these have not

\footnotetext{
* Corresponding author: K. Pisarska, Department of Plant Protection, Agriculture Microbiology Laboratory, Wrocław University of Environmental and Life Science, Wrocław, Poland; e-mail: katarzyna.pisarska@up.wroc.pl
} 
focused on maize grown in the European temperate climate zone, where abiotic factors are drastically different from the ones in regions of long lasting history of maize cultivation. The origin of endophytic bacteria in aboveground tissues of maize is still discussable. JohnstonMonje and Raizada (2011) pointed out that endophytic bacteria of maize cultivars and breeding lines originated from Central America and cultivated in North America are transmitted with the seeds from one generation to another. However, Rijavec et al. (2007) isolated sporadically bacteria from germinated seeds of maize harvested in Slovenia. Rijavec et al. (2007) among isolated species from maize seedlings identified Pantoea anantis as the predominating bacteria. This species recently was described as pathogenic for maize in America and in Central Europe (Pérez-y-Terrón et al., 2009; Krawczyk et al., 2010). Furthermore, a study in southern China revealed significant modification and simplification of diversity of EnB in seeds during maturation, especially in the case of hybrid cultivars (Liu et al., 2012; 2013). Also, Liu et al. $(2012 ; 2013)$ did not identify stable core associations of bacterial species inhabiting seeds of parent lines as well as seeds of hybrid cultivars originated from these breeding lines. Still little is known about diversity of endophytic bacteria associated with different hybrid maize cultivars in the temperate climate zone cropped under field conditions. Better knowledge could help us to search new potential Plant Growth Promoting Bacteria (PGPB) for agricultural applications since cultivable bacteria are potentially good candidates for commercialization (Xu et al., 2013).

In this paper we focus on a comparative study of biodiversity of cultivable dominant EnB of different hybrid cultivars of maize. For this purpose we isolated bacteria from plant tissues of six maize cultivars sown from the same lots of seeds in two locations on different soils as well as grown in vitro. The aims of the study were to evaluate the hypotheses that core associations of EnB cultivable species in aboveground parts of maize are similar or are connected with specific cultivars independently of environmental factors.

\section{Experimental}

\section{Material and Methods}

Plant material and cultivation condition. Plant material was collected from two experimental fields of Małopolska Plant Growing Company - HBP LLC at Kobierzyce (50 $58^{\prime} \mathrm{N}, 1^{\circ} 55^{\prime} \mathrm{E}$ Kobierzyce, Poland) and at Smolice $\left(51^{\circ} 42^{\prime} \mathrm{N}, 17^{\circ} 10^{\prime} \mathrm{E}\right.$ Smolice, Poland). Six cultivars of maize (Zea mays L. spp. mays) (single hybrids; KB1902, KB1903 and triple hybrids; KB2704, Kosmo230, Cyrkon, Król) listed in Table I were sown in May 2009. The tested 6 maize cultivars were released from Kobierzyce Seed Centre (Kobierzyce, Poland) of Małopolska Plant Growing Company - HBP LLC (Poland). Complete cultivar vouchers are available from the Central Laboratory for Studies of Cultivable Plants "COBORU" (Slupia Wielka, Poland). Plants (three per cultivar per location) were collected at the $\mathrm{BBCH}$ 18-19 stage. At both locations $~ 85000$ seeds $\mathrm{ha}^{-1}$ of tested cultivars were sown. They were sown in Kobierzyce on gleyic chernozemic (siltic) soil $\left(\mathrm{pH}_{\mathrm{KCl}} 7.1\right.$; $\mathrm{C}_{\text {org }}$ $1.94 \%)$. The contents of plant available macro nutrients in the soil were as follows; phosphorus $\sim 250 \mathrm{mg}$ $\mathrm{P} 1 \mathrm{~kg}$ d.m. ${ }^{-1}$, potassium $460 \mathrm{mg} \mathrm{K} 1 \mathrm{~kg} \mathrm{d.m.} .^{-1}$ and magnesium $\sim 57 \mathrm{mg} \mathrm{Mg} 1 \mathrm{~kg} \mathrm{d.m.} .^{-1}$. Winter wheat was a pre-crop and before sowing plots was fertilized with nitrogen, phosphorus and potassium at the level of 130, 40 and $82 \mathrm{~kg} \mathrm{ha}^{-1}$, respectively. In Smolice maize plants were cultivated on haplic luvisols (loamic) soil $\left(\mathrm{pH}_{\mathrm{KCl}} 6.2 ; \mathrm{C}_{\text {org. }} 1.45 \%\right)$ and the contents of plant available macro nutrients were as follows; phosphorus $\sim 250 \mathrm{mg}$ P $1 \mathrm{~kg} \mathrm{~d} . \mathrm{m}^{-1}{ }^{\text {, }}$ potassium $230 \mathrm{mg} \mathrm{K} 1 \mathrm{~kg} \mathrm{~d} . \mathrm{m} .{ }^{-1}$ and magnesium $\sim 62 \mathrm{mg} \mathrm{Mg} 1 \mathrm{~kg}$ d.m. ${ }^{-1}$. Maize was a pre-crop and before sowing plots was fertilized with nitrogen, phosphorus and potassium at the level of 138, 45 and $95 \mathrm{~kg} \mathrm{ha}^{-1}$, respectively.

Seedlings of tested maize cultivars grown in vitro were used in experiments as well. Seeds of six cultivars were hand-shelled from cobs harvested in October 2009 from both sampling sites and surface-sterilized with

Table I

Information about seeds, their parental lines and area of application

\begin{tabular}{|l|c|c|c|c|c|l|}
\hline \multirow{2}{*}{$\begin{array}{l}\text { Zea mays } \\
\text { cultivar }\end{array}$} & \multirow{2}{*}{ Type } & \multirow{2}{*}{ FAO } & \multirow{2}{*}{ Grain type } & \multicolumn{2}{c|}{ Registry form } & \multirow{2}{*}{ Area of use } \\
\cline { 5 - 6 } & & & & mother & father & \multirow{2}{*}{} \\
\hline KB1902 & SC $^{*}$ & 190 & flint-dent & S, I.D & D & grain \\
\hline KB1903 & SC & 190 & flint-dent & L.D, D & D & grain \\
\hline KB2704 & TC & 270 & flint-dent & S, D $\times$ S, I.D. & F & grain; livestock feed \\
\hline KRÓL & TC & 270 & flint-dent & D & F & livestock feed \\
\hline KOSMO230 & TC & 240 & flint-dent & D & D & grain; livestock feed \\
\hline CYRKON & TC & 250 & flint-dent & D & F & livestock feed \\
\hline
\end{tabular}

* SC - single cross, TC - triple cross

** S - semident; I.D. - lodent; L.D. - light dent; D - dent; F - flint 
$1 \% \mathrm{NaClO}^{-}$for 30 minutes. Then they were washed three times with sterile $\mathrm{dH}_{2} \mathrm{O}(2 \times 5 \mathrm{~min}, 1 \times 90 \mathrm{~min}$. $)$ and placed in test tubes with $0.8 \%$ agar supplemented with $21 \mathrm{ppm}$ Hoagland solution (Hoagland and Arnon, 1950). Test tubes plants were incubated in a growth chamber at 14 hours daylight, temperature of $22^{\circ} \mathrm{C}$, $16^{\circ} \mathrm{C}$ night temperature until the third leaf appears. We analyzed 2-3 seeds from each cultivar collected from both locations separately.

Endophytes isolation and cultivation. Aboveground parts of maize were collected from both testing locations and immediately after cutting were put into sterile bags and kept at $+4^{\circ} \mathrm{C}$ during transfer to the laboratory. Isolations were done about 2-3 hours later. Plants leaves were surface-sterilized with $70 \%$ $\mathrm{C}_{2} \mathrm{H}_{5} \mathrm{OH}$ and subsequently washed 3-times with sterile distilled water. Field samples of leaves for endophyte isolation were cut out of bigger sterilized leaves fragments into $\sim 6 \mathrm{~cm}^{2}$ pieces from the center part of the leaf with a sterile blade. The whole plants grown in vitro, at the stage of third true leaf were separated into three parts (roots, stems, leaves), and after mentioned above surface-disinfection used for analysis as well.

Each sample after surface-sterilization was macerated in aseptic $0.1 \mathrm{M} \mathrm{MgSO}_{4}$ and ten-fold diluted suspensions were transferred onto solid 1/3 TSA (Difco, USA) medium for field and in vitro samples. Additionally, macerated plant samples of in vitro plants were transferred onto Rojo Congo (RC) medium (Rodríguez Cáceres, 1982) for enumeration of cultivable nitrogenfixing bacteria. Plates were incubated at $28^{\circ} \mathrm{C}$ by 7 days. After incubation from each sample 10-12 dominating, morphologically differentiated bacterial colonies were randomly picked and used for further tests. Three consecutive transfers onto 1/3 TSA medium were done to obtain single colony cultures. Pure strains were maintained as frozen stocks at $-70^{\circ} \mathrm{C}$ in a storage medium (Bactotryptone $10 \mathrm{~g}$; yeast extract $5 \mathrm{~g} ; \mathrm{NaCl} 0.5 \mathrm{~g}$; $\mathrm{K}_{2} \mathrm{HPO}_{4} 6.3 \mathrm{~g} ; \mathrm{KH}_{2} \mathrm{PO}_{4} 1.8 \mathrm{~g}$; sodium citrate $0.45 \mathrm{~g}$; $\mathrm{MgSO}_{4} \times 7 \mathrm{H}_{2} \mathrm{O} 0.09 \mathrm{~g} ;\left(\mathrm{NH}_{4}\right)_{2} \mathrm{SO}_{4} 0.9 \mathrm{~g} ; 1000 \mathrm{ml} \mathrm{d} \mathrm{H}_{2} \mathrm{O}$; $\mathrm{pH}$ 7.0). Surface sterilization parameters like selection of disinfectant; its strength and time were optimized prior experimentation with pot cultivated maize plants (data not shown).

DNA isolation and 16S rRNA gene sequencing. Selected single isolates were cultivated on solid King B or PDA medium. Genomic DNA was extracted using the Genomic Mini AX Bacteria kit (AA Biotechnology, Poland) according to the instructions of the manufacturer. Amplified fragments of the 16S rRNA gene were generated by PCR with the primers FAM27f (5'-GAGTTTGATCMTGGCTCAG-3') and 1492r (5'-GGYTACCTTGTTACGACTT-3') and 5x Hot FIREPol Blend Master Mix (Solis Biodyne, Estonia). The PCR products were purified with the PureLinkTM
Genomic DNA Mini Kit (Invitrogen, USA) or ExoSAPIT (GE Healthcare Life Sciences, USA) in accordance with the manufacturer's protocol. Sequencing of the amplified 16S rRNA gene fragments was carried out with primers FAM27f and 1492r, which annealed to either end of the gene, as well as with primers $704 \mathrm{f}$ (5'-TGTGTAGCGGTGAAATGCGTAGA-3') and 765r (5'-CTGTTTGCTCCCCACGCTTTC-3'), which annealed to the central portions of the gene. Sequencing was performed on ABI 3730X1 DNA Analyzer (Applied Biosystems, Foster, USA). The obtained sequences were aligned using the ClustalW method of the DNAStar software package (DNAStar Lasergene Inc., USA). A BLASTN search of the NCBI database and search of the RDP database were performed to compare the 16S rRNA gene sequences of isolates with those available online.

Statistical analysis. Data were analyzed statistically using Statistica V.9.0PL (StaSoft Inc., USA) software. Duncan's multiple range test was used to assess the differences among the means (three replicates for each) at $95 \%$ level of significance $(\mathrm{P}=0.05)$.

\section{Results}

Isolation of endophytic bacteria. We did not isolate bacteria able to grown on 1/3 TSA or RC medium from any of twenty-eight 15-20-d old seedlings of examined maize cultivars germinated from surface sterilized seeds and cultivated in vitro.

The enumeration of CFU of cultivable endophytic bacteria inhabited leaves of tested six maize cultivars revealed significant differences among them as well as between both cultivation plots (Table II). The CFU number enumerated in leaves collected from maize cultivated in Smolice ranged from 5.43 to $6.26 \log 10 \mathrm{CFU}$ $(1 \mathrm{~g} \mathrm{~d} . w)^{-1}$ and from 4.63 to $5.73 \log 10 \mathrm{CFU}(1 \mathrm{~g} \text { d.w. })^{-1}$ in leaves collected from maize cultivated in Kobierzyce. The number of $\log 10 \mathrm{CFU}$ in leaves of all cultivars was significantly higher in plants cultivated in Smolice than in Kobierzyce (Table II). The highest $\log 10$ CFU numbers were found in leaves of Kosmo $230 \mathrm{cv}$. in comparison with other maize cultivars (Table II), where the $\log 10$ CFU numbers were not statistically different.

Isolates identification. The dominant, morphologically differentiated bacterial colonies, in total, 125 isolates, representing six maize cultivars planted in two sampling sites were identified based on partial 16S RNA gene sequence. Overall, the isolates represented five taxonomic divisions: Actinobacteria, Bacteroidetes, Firmicutes as well as $\alpha$ - and $\gamma$-Proteobacteria. The most common phyla were $\gamma$-Proteobacteria and Actinobacteria, $40 \%$ and $26.4 \%$ of all isolates, respectively. Phyla $\gamma$-Proteobacteria was detected in all tested plants, in contrary to a-Proteobacteria detected only in five (out 
Table II

Number of colony forming units of bacteria grown on 1/3 TSA (log10 CFU per g d.w. of leaf tissue) in leaf tissue of six maize cultivars

\begin{tabular}{|l|c|c|c|c|}
\hline \multirow{2}{*}{ Zea mays cultivar } & \multicolumn{3}{c|}{ Number of selected isolates } & \multirow{2}{*}{$\begin{array}{c}\text { Number of } \\
\text { selected isolates }\end{array}$} \\
\cline { 2 - 4 } & Smolice & Kobierzyce & Means for cultivar & 21 \\
\hline KB1902 & $5.79^{\mathrm{a}-\mathrm{b}}$ & $4.20^{\mathrm{b}-\mathrm{d}}$ & $5.30^{\mathrm{B}}$ & 19 \\
\hline KB1903 & $5.45^{\mathrm{a}-\mathrm{d}}$ & $5.02^{\mathrm{b}-\mathrm{d}}$ & $5.23^{\mathrm{B}}$ & 23 \\
\hline KB2704 & $5.43^{\mathrm{a}-\mathrm{d}}$ & $4.72^{\mathrm{c}-\mathrm{d}}$ & $5.07^{\mathrm{B}}$ & 22 \\
\hline KRÓL & $5.57^{\mathrm{a}-\mathrm{d}}$ & $4.63^{\mathrm{d}}$ & $5.10^{\mathrm{B}}$ & 20 \\
\hline KOSMO230 & $6.26^{\mathrm{a}}$ & $5.73^{\mathrm{a}-\mathrm{c}}$ & $5.99^{\mathrm{A}}$ & 20 \\
\hline CYRKON & $5.81^{\mathrm{a}-\mathrm{b}}$ & $4.79^{\mathrm{b}-\mathrm{d}}$ & $5.30^{\mathrm{B}}$ & --- \\
\hline Means for localization & $5.72^{\mathrm{a}}$ & $4.95^{\mathrm{B}}$ & --- & 125 \\
\hline Number of selected isolates & 64 & 61 & --- & \\
\hline
\end{tabular}

Values for cultivars at both locations followed by the same small letter, means for cultivar followed by the same capital letter and means for localization followed by the same Greek letter are not significantly different according to Duncan's multiple range test $(\mathrm{P}<0.05)$

of six) cultivars grown in Kobierzyce location, only. Phyla Actinobacteria was detected in ten out of twelve plants, except Kosmo 230 cv. and Król cv. from Kobierzyce and Smolice sampling sites respectively (Fig. 1). Altogether, identified bacteria represented 46 species from 18 genera. Higher diversity of EnB was found in plants collected from Kobierzyce, where we identified 35 species from 16 genera and among them 22 species were uniquely found at this field, only. In the contrary, from maize leaves collected at Smolice we identified 24 species representing 10 genera and among them 10 species were uniquely isolated from this field (Table III). The most frequently encountered genera were Pseudomonas (33.6\%), Bacillus (17.6\%), Arthrobacter (11.2\%) and Microbacterium (9.6\%). Strains belonging to Pseudomonas genus were isolated from all tested plants except KB2704 cv. grown in Kobierzyce. Strains of Pseudomonas fluorescens were most frequently isolated in leaves tissues of five cultivars expect Cyrkon cropped at Smolice. Aforementioned, species was found in leaves of two cultivars, Król and Kosmo230, cultivated at Kobierzyce, only. Among Bacillus, a second dominated genus, strains of Bacillus megaterium were most frequently isolated. This species was found in leaves of five cultivars cropped at Smolice, expect of cultivar KB1902, but was isolated only from tested tissues of Cyrkon grown at Kobierzyce. Among Arthrobacter genus, Arthrobacter. nicotinovorans was the most frequently isolated species. They were found in leaves of KB2704 and Król collected at Kobierzyce, KB1903 and Cyrkon collected at Smolice as well as in tissues of KB1902 collected from both

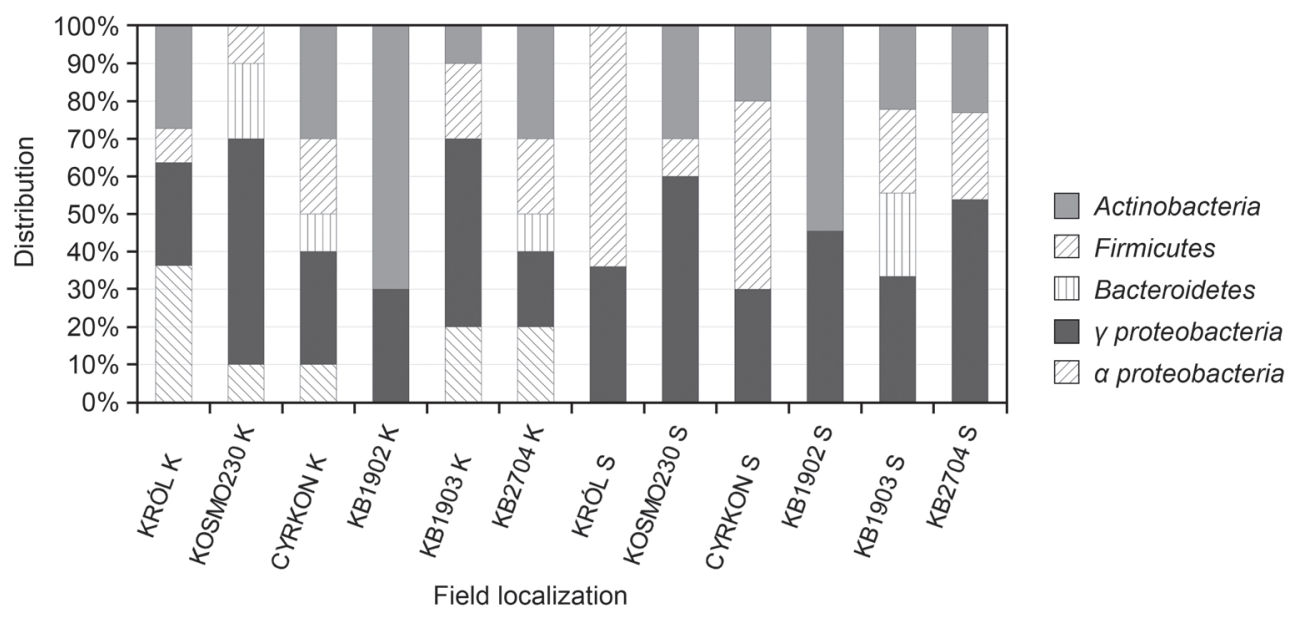

Fig. 1. Phylogenetic distribution of endophytic bacteria at phyla/class level expressed per host-plant species per localization. Bacteria were classified based on $16 S$ rRNA gene data with ClustalW method of the DNAStar software package (DNAStar Lasergene Inc., USA). A BLASTN search of the NCBI database and search of the RDP database were performed to compare the 16S rRNA gene sequences of isolates with those available online. Samples are labeled with letters indicating sampling site ( $\mathrm{S}$ - Smolice, K - Kobierzyce) 
Table III

Identification of endophytes isolated from leaves of six maize cultivars grown on two different fields.

\begin{tabular}{|c|c|c|c|c|c|c|c|c|c|c|c|c|c|c|c|c|}
\hline \multirow{4}{*}{ 竞 } & \multirow{4}{*}{ Genus } & \multirow{2}{*}{\multicolumn{2}{|c|}{$\begin{array}{c}\text { Closest match according to the } 16 \mathrm{~S} \text { rRNA } \\
\text { gene sequence }\end{array}$}} & \multirow{4}{*}{ 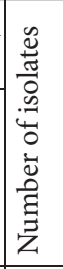 } & \multicolumn{12}{|c|}{ Field localization and Zea mays cultivar } \\
\hline & & & & & \multirow{2}{*}{ 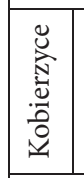 } & \multirow[b]{2}{*}{ 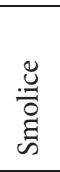 } & \multirow{2}{*}{ 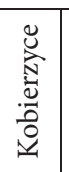 } & \multirow[b]{2}{*}{ 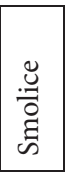 } & \multirow{2}{*}{ 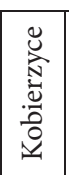 } & \multirow[b]{2}{*}{ 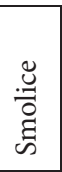 } & \multirow{2}{*}{ 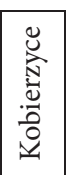 } & \multirow[b]{2}{*}{ 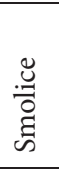 } & \multirow{2}{*}{ 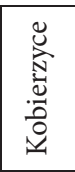 } & \multirow[b]{2}{*}{ 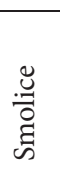 } & \multirow{2}{*}{ 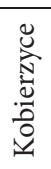 } & \\
\hline & & \multirow[t]{2}{*}{$\begin{array}{l}\text { Nearest relative } \\
\text { strains }\end{array}$} & \multirow{2}{*}{$\begin{array}{c}\text { Acces. No. } \\
\text { of nearest relative } \\
\text { strain } \\
\left(\% \text { of the match }{ }^{*}\right)\end{array}$} & & & & & & & & & & & & & 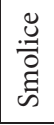 \\
\hline & & & & & KB1 & 1902 & KB1 & 903 & $\mathrm{~KB}$ & 704 & $\mathrm{~K}$ & ól & Kosn & 0230 & $\mathrm{Cy}$ & kon \\
\hline & Methylobacterium & M. aminovorans & AB175629 (99.1) & 2 & 0 & 0 & 0 & 0 & 0 & 0 & 2 & 0 & 0 & 0 & 0 & 0 \\
\hline$\frac{2}{2}$ & & M. extorquens & D32224 (99.6) & 2 & 0 & 0 & 0 & 0 & 0 & 0 & 2 & 0 & 0 & 0 & 0 & 0 \\
\hline $\begin{array}{l}\tilde{U} \\
0\end{array}$ & Rhizobium & Rh. radiobacter & AB247615 (97.0) & 3 & 0 & 0 & 2 & 0 & 0 & 0 & 0 & 0 & 1 & 0 & 0 & 0 \\
\hline ¿ँ & & Rh. larrymoorei & Z30542 (98.7) & 1 & 0 & 0 & 0 & 0 & 1 & 0 & 0 & 0 & 0 & 0 & 0 & 0 \\
\hline$\frac{5}{1}$ & Sphingomonas & Sph.glacialis & GQ253122 (98.0) & 1 & 0 & 0 & 0 & 0 & 1 & 0 & 0 & 0 & 0 & 0 & 0 & 0 \\
\hline & & Sph.paucimobilis & U37337 (99.5) & 1 & 0 & 0 & 0 & 0 & 0 & 0 & 0 & 0 & 0 & 0 & 1 & 0 \\
\hline & Acinetobacter & Ac. calcoaceticus & AJ888983 (98.6) & 2 & 0 & 0 & 0 & 0 & 2 & 0 & 0 & 0 & 0 & 0 & 0 & 0 \\
\hline & & Ac. lwoffi & X81665 (99.1) & 3 & 0 & 0 & 0 & 0 & 0 & 0 & 0 & 0 & 3 & 0 & 0 & 0 \\
\hline & & Ac.schindleri & AJ278311 (98.3) & 1 & 0 & 0 & 0 & 0 & 0 & 0 & 0 & 1 & 0 & 0 & 0 & 0 \\
\hline & Erwinia & E.persicina & U80205 (99.2) & 1 & 0 & 0 & 0 & 0 & 0 & 0 & 0 & 0 & 0 & 1 & 0 & 0 \\
\hline & Pseudomonas & Ps. clemancea & AM419155 (98.7) & 4 & 0 & 0 & 0 & 1 & 0 & 0 & 0 & 0 & 0 & 0 & 1 & 2 \\
\hline & & Ps. extremaustralis & AJ583501 (99.9) & 1 & 0 & 0 & 0 & 0 & 0 & 0 & 0 & 1 & 0 & 0 & 0 & 0 \\
\hline & & Ps. fluorescens & AF094729 (99.9) & 1 & 0 & 0 & 0 & 0 & 0 & 0 & 0 & 0 & 0 & 0 & 0 & 1 \\
\hline$\frac{\sqrt[3]{7}}{0}$ & & Ps. fluorescens & AJ308307 (99.5) & 16 & 0 & 3 & 0 & 2 & 0 & 4 & 1 & 2 & 2 & 2 & 0 & 0 \\
\hline 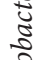 & & Ps. graminis & Y11150 (99.8) & 1 & 0 & 0 & 0 & 0 & 0 & 0 & 0 & 0 & 0 & 1 & 0 & 0 \\
\hline : & & Ps. grimontii & AF268029 (99.9) & 3 & 2 & 0 & 0 & 0 & 0 & 0 & 0 & 0 & 0 & 0 & 1 & 0 \\
\hline$\frac{5}{1}$ & & Ps. lurida & AJ581999 (99.9) & 3 & 0 & 2 & 0 & 0 & 0 & 1 & 0 & 0 & 0 & 0 & 0 & 0 \\
\hline & & Ps. marginalis & Z76663 (99.4) & 4 & 1 & 0 & 2 & 0 & 0 & 0 & 0 & 0 & 0 & 1 & 0 & 0 \\
\hline & & \begin{tabular}{|l|} 
Ps. migulae \\
\end{tabular} & AF074383 (99.7) & 1 & 0 & 0 & 0 & 0 & 0 & 0 & 0 & 0 & 0 & 0 & 0 & 1 \\
\hline & & Ps. orientsalis & AF064457 (99.6) & 4 & 0 & 0 & 0 & 0 & 0 & 1 & 2 & 0 & 1 & 0 & 0 & 0 \\
\hline & & \begin{tabular}{|l|} 
Ps.poae \\
\end{tabular} & AJ492829 (99.9) & 2 & 0 & 0 & 0 & 0 & 0 & 1 & 0 & 0 & 0 & 0 & 1 & 0 \\
\hline & & Ps. thievervalensis & AF100323 (99.5) & 2 & 0 & 0 & 2 & 0 & 0 & 0 & 0 & 0 & 0 & 0 & 0 & 0 \\
\hline & & Ps. viridiflava & AY180972 (99.8) & 1 & 0 & 0 & 1 & 0 & 0 & 0 & 0 & 0 & 0 & 0 & 0 & 0 \\
\hline & Shigella & S. flexneri & X96963 (98.1) & 1 & 0 & 0 & 0 & 0 & 0 & 0 & 0 & 0 & 0 & 1 & 0 & 0 \\
\hline & Arthrobacter & Ar. nicotinovorans & X80743 (99.6) & 10 & 2 & 2 & 0 & 1 & 1 & 0 & 2 & 0 & 0 & 0 & 0 & 2 \\
\hline & & Ar. nitroguajacolicus & AJ512504 (99.8) & 4 & 1 & 0 & 1 & 1 & 0 & 0 & 0 & 0 & 0 & 0 & 1 & 0 \\
\hline & Brahybacterium & Br. conglomeratum & AB537169 (100.0) & 1 & 1 & 0 & 0 & 0 & 0 & 0 & 0 & 0 & 0 & 0 & 0 & 0 \\
\hline$\frac{2}{8}$ & Kocuria & K. rhizophila & Y16264 (97.3) & 1 & 0 & 0 & 0 & 0 & 0 & 1 & 0 & 0 & 0 & 0 & 0 & 0 \\
\hline 艺 & & K. kristinae & X80749 (99.4) & 1 & 0 & 0 & 0 & 0 & 1 & 0 & 0 & 0 & 0 & 0 & 0 & 0 \\
\hline ఏ & Microbacterium & M. phyllosphere & AJ277840 (98.4) & 1 & 0 & 0 & 0 & 0 & 0 & 0 & 0 & 0 & 0 & 1 & 0 & 0 \\
\hline 葉 & & M. testaceum & X77445 (98.0) & 11 & 0 & 4 & 0 & 0 & 0 & 2 & 1 & 0 & 0 & 2 & 2 & 0 \\
\hline & Micrococcus & M. yunnanensis & FJ214355 (99.9) & 1 & 0 & 0 & 0 & 0 & 1 & 0 & 0 & 0 & 0 & 0 & 0 & 0 \\
\hline & Rhodococcus & Rh. qingshengii & DQ090961 (99.6) & 1 & 1 & 0 & 0 & 0 & 0 & 0 & 0 & 0 & 0 & 0 & 0 & 0 \\
\hline & Rothia & R. amarae & AY043359 (99.4) & 2 & 2 & 0 & 0 & 0 & 0 & 0 & 0 & 0 & 0 & 0 & 0 & 0 \\
\hline$\approx$ & Chryseobacterium & Chr. indoltheticum & AY468448 (99.1) & 1 & 0 & 0 & 0 & 0 & 0 & 0 & 0 & 0 & 1 & 0 & 0 & 0 \\
\hline 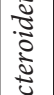 & & Chr. jejuense & EF591303 (97.3) & 3 & 0 & 0 & 0 & 2 & 0 & 0 & 0 & 0 & 0 & 0 & 1 & 0 \\
\hline 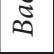 & Pedobacter & P. borealis & EU030687 (98.8) & 2 & 0 & 0 & 0 & 0 & 1 & 0 & 0 & 0 & 1 & 0 & 0 & 0 \\
\hline & Bacillus & B. aerophilus & AJ831844 (99.4) & 3 & 0 & 0 & 0 & 0 & 0 & 0 & 0 & 2 & 1 & 0 & 0 & 0 \\
\hline 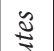 & & B. circulans & AY724690 (99.5) & 4 & 0 & 0 & 0 & 0 & 0 & 2 & 0 & 2 & 0 & 0 & 0 & 0 \\
\hline 胥 & & B. idriensis & AY904033 (99.9) & 1 & 0 & 0 & 0 & 0 & 1 & 0 & 0 & 0 & 0 & 0 & 0 & 0 \\
\hline 这 & & B. megaterium & D16273 (98.7) & 10 & 0 & 0 & 0 & 1 & 0 & 1 & 0 & 2 & 0 & 1 & 1 & 4 \\
\hline & & B. methylotrophicus & EU194897 (99.5) & 1 & 0 & 0 & 1 & 0 & 0 & 0 & 0 & 0 & 0 & 0 & 0 & 0 \\
\hline
\end{tabular}


Table III

Continued

\begin{tabular}{|c|c|c|c|c|c|c|c|c|c|c|c|c|c|c|c|c|}
\hline \multirow{4}{*}{ 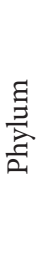 } & \multirow{4}{*}{ Genus } & \multirow{2}{*}{\multicolumn{2}{|c|}{$\begin{array}{c}\text { Closest match according to the } 16 \mathrm{~S} \text { rRNA } \\
\text { gene sequence }\end{array}$}} & \multirow{4}{*}{ 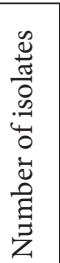 } & \multicolumn{12}{|c|}{ Field localization and Zea mays cultivar } \\
\hline & & & & & \multirow{2}{*}{ 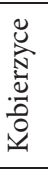 } & \multirow[b]{2}{*}{ 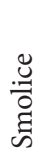 } & \multirow{2}{*}{ 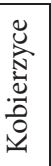 } & \multirow[b]{2}{*}{ 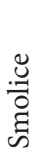 } & \multirow{2}{*}{ 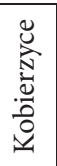 } & \multirow[b]{2}{*}{ 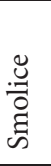 } & \multirow{2}{*}{ 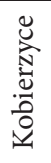 } & \multirow[b]{2}{*}{ 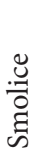 } & \multirow{2}{*}{ 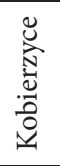 } & \multirow[b]{2}{*}{$\begin{array}{l}\stackrel{\mathscr{z}}{.0} \\
\text { מี }\end{array}$} & \multirow{2}{*}{ 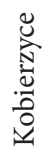 } & \multirow[b]{2}{*}{ 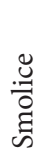 } \\
\hline & & $\begin{array}{l}\text { Nearest relative } \\
\text { strains }\end{array}$ & $\begin{array}{c}\text { Acces. No. } \\
\text { of nearest relative } \\
\text { strain }\end{array}$ & & & & & & & & & & & & & \\
\hline & & & $\left(\%\right.$ of the match $\left.{ }^{*}\right)$ & & \multicolumn{2}{|c|}{ KB1902 } & \multicolumn{2}{|c|}{ KB1903 } & \multicolumn{2}{|c|}{ KB2704 } & \multicolumn{2}{|c|}{ Król } & \multicolumn{2}{|c|}{ Kosmo230 } & \multicolumn{2}{|c|}{ Cyrkon } \\
\hline \multirow{5}{*}{ 芯 } & \multirow[t]{2}{*}{ Bacillus } & B.pumilus & AY876289 (97.9) & 1 & 0 & 0 & 0 & 0 & 0 & 0 & 0 & 0 & 0 & 0 & 0 & 1 \\
\hline & & B. simplex & AJ439078 (98.6) & 2 & 0 & 0 & 0 & 0 & 0 & 0 & 1 & 1 & 0 & 0 & 0 & 0 \\
\hline & \multirow[t]{3}{*}{ Staphylococcus } & St. haemolyticus & X66100 (99.2) & 2 & 0 & 0 & 0 & 1 & 1 & 0 & 0 & 0 & 0 & 0 & 0 & 0 \\
\hline & & St.pasteuri & AB009944 (99.3) & 1 & 0 & 0 & 0 & 0 & 0 & 0 & 0 & 0 & 0 & 0 & 1 & 0 \\
\hline & & St. saprophyticus & AP008934 (99.3) & 1 & 0 & 0 & 1 & 0 & 0 & 0 & 0 & 0 & 0 & 0 & 0 & 0 \\
\hline & \multicolumn{3}{|c|}{ Number of species } & 46 & 7 & 4 & 7 & 7 & 9 & 8 & 7 & 7 & 7 & 8 & 9 & 6 \\
\hline & \multicolumn{3}{|c|}{ Number of species unique for cultivar in Kobierzyce } & $\mathrm{X}$ & 3 & & 4 & & 6 & & 2 & & 2 & & 2 & \\
\hline & \multicolumn{3}{|c|}{ Number of species unique for cultivar in Smolice } & $\mathrm{X}$ & & 0 & & 0 & & 1 & & 2 & & 4 & & 2 \\
\hline & \multicolumn{3}{|c|}{ Number of species unique for cultivar at both locations } & & \multicolumn{2}{|c|}{ 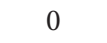 } & \multicolumn{2}{|c|}{0} & \multicolumn{2}{|c|}{0} & & L & & & & 0 \\
\hline & Number of spec & common for cultiv & at both locations & & & 1 & 1 & & c & & & 2 & & & & 2 \\
\hline & $\begin{array}{l}\text { Number of spec } \\
\text { on field Kobierz }\end{array}$ & uniquely isolated $\mathrm{fr}$ & maize grown & & & & & & & & & & & & & \\
\hline & $\begin{array}{l}\text { Number of spec } \\
\text { on field in Smol }\end{array}$ & uniquely isolated $\mathrm{fr}$ & maize grown & & & & & & & & & & & & & \\
\hline
\end{tabular}

* gave for the lowest value

locations. Strains of Microbacterium testaceum, which were most frequently isolated among Microbacterium genus, were found in leaves of two cultivars cropped at Kobierzyce (Król, Cyrkon) and three cultivars cropped at Smolice (KB1902, KB2704 and Kosmo230).

However, none of species was common for all cultivars at both locations (Table III). Among isolated EnB six species only, Pseudomonas clemancea, P. fluorescens, B. megaterium, Bacillus simplex, Ar. nicotinovorans and Arthrobacter nitroguajacolicus, were found in aboveground parts of the same cultivar grown on both tested fields (Table III).

There were differences in number of unique species based on cultivar source. Cultivar KB1902 was inhabited by three unique species (Brachybacterium conglomeratum, Rhodococcus qingshengii, Rothia amarae) in Kobierzyce but we did not found any unique one in cultivar cropped in Smolice. Likewise cultivar KB1903 was inhabited by four unique species (Bacillus methylotrophicus, Pseudomonas thievervalensis, Pseudomonas viridiflava, Staphylococcus saprophyticus) in Kobierzyce but we did not found any unique one in cultivar cropped in Smolice. On the contrary, other four cultivars were inhabited by unique species in both locations (Table III). For example, Król cultivar was inhabited by two unique species in Kobierzyce (Methylobacterium aminovorans, Methylobacterium extorquens) and by two unique species in Smolice (Acinteobacter schindlerii, Pseudomonas extremaustralis).

\section{Discussion}

Genotypic diversity of endophytes. This study was an attempt to isolate and characterize endophytes of six maize cultivars inhabiting young seedlings germinated from surface-sterilized maize seeds in vitro as well as from leaves of these cultivars cropped at two locations with culture-dependent approach. Our approach did not result in the isolation of cultivable endophytes from seedlings germinated from second generation of seeds of tested cultivars on organic medium (1/3 TSA) as well as on RC medium used for isolation of nitrogen-fixing bacteria. This may suggest that seeds did not harbour cultivable endophytic bacteria colonizing seedlings. However, Johnston-Monje and Raizada (2011) isolated cultivable bacteria and identified several non-cultivable bacteria in seeds of wild ancestors (teosinte) and domesticated varieties of maize. They pointed out that bacteria are transmitted with the seeds from one generation to another. Among investigated seeds Johnston-Monje and Raizada (2011) tested seeds of two commercial cultivars, dent inbred B73 and hybrid Pioneer 3751, which in our opinion are similar to seeds of commercial cultivars tested in our studies. They were able to isolate on three diverse media cultivable bacteria from the genus Bacillus and Enterobacter from the second generation of seeds of hybrid Pioneer 3751 but not from the seeds of inbred B73. Also Rijavec et al. (2007) did not isolate cultivable 
bacteria from most of tested germinated kernels of different maize cultivars collected in Slovenia (16 strains from 195 tested germinated seeds). They were able to isolate bacteria from $11 \%$ to $20 \%$ of tested germinated seeds of different cultivars and the lowest number of germinated seeds inhabited by EnB was found in the case of non-named Pioneer inbreed. Among isolated bacteria, 5 out of 15 isolates Rijavec et al. (2007) identified as Pantoea anantis, which recently was described as a pathogenic for maize species in America and in Central Europe (Pérez-y-Terrón et al., 2009; Krawczyk et al., 2010). A similar study on the diversity of endophytic bacteria in seeds with non-culture method reported by Liu et al. (2012) also revealed a generally lower number of species in seeds of hybrid than in seeds of parental lines. Lack of cultivable endophytic bacteria in young seedlings of tested maize cultivars grown in vitro could reflect the effect of inbreeding similar like in the case of seeds of inbreed B73 (Johnston-Monje and Raizada, 2011). Noticeable smaller biodiversity of cultivable and non-cultivable EnB and even lack of cultivable EnB in self-pollinated seeds of second generation of wild ancestors as well as Mexican maize landraces collected on field near Guelph (Canada) was described also by Johnston-Monje and Raizada (2011).

The influence of different environmental condition, especially temperature during maturation of seeds is another factor that should be taken into consideration, explaining the lack of cultivable endophytic bacteria in young seedlings maize hybrid cultivars tested in our studies. Harvest of maize seeds for our studies in October 2009 was done after night frost, which probably did not support the survival of endophytic bacteria in our seeds. Liu et al. (2013) also reported significant decrease of biodiversity of EnB communities in seeds of two cultivars from proembryo-forming stage to dough stage. Mentioned above research and our results support hypotheses that environmental conditions like fertilization, soil properties, weather conditions during maturation as well as maturation stage of seeds are important factors limiting the survival and biodiversity of $\mathrm{EnB}$ communities in seeds of maize regard inbreed effect.

The results of the study of dominant endophytic bacteria isolated from leaves tissues of six maize cultivars grown under field condition show different composition of cultivable bacteria and noticeable cultivar and location dependent diversity between these associations. However, among EnB isolated from leaves, bacteria from the phylum $\gamma$-Proteobacteria with the genus Pseudomonas were the most often encountered. Several authors also reported that among endophytic bacteria Pseudomonas were frequently isolated and were found to be present in tissues of sugar beet (Jacobs et al., 1985), carrot (Surette et al., 2003), soybean (Kuklinsky-
Sorbal et al., 2004), ginseng (Cho et al., 2007), maize (McInroy and Kloepper, 1995; Rai et al., 2007; Rijavec et al., 2007) as well as in maize kernels (JohnstonMonje and Raizada, 2011; Liu et al., 2012). Frequently encountered genera were also Bacillus, Arthrobacter and Microbacterium. Aforementioned genera have been previously described as maize endophytes (McInroy and Kloepper, 1995; Rai et al., 2007; Rijavec et al., 2007; Liu et al., 2013). Studies of Johnston-Monje and Raizada (2011) showed that TRFLP method predicted Clostridium and Paenibacillus species as conserved across all studied Zea genotypes. In contrary, studies by Liu et al. (2012) on four Chinese maize hybrids and their parental lines showed that the genus Paenibacillus was present only in two parental lines (Ye478; Chang 7-2) but its hybrid Yuyu 23 did not harbour them. Moreover, second conserved genus Clostridium has not been identified among Chinese cultivars. In this study we did not reported genus Paenibacillus or Clostridium harbouring maize leaf tissues. Species common to the Polish and Chinese maize hybrids were Acinetobacter lwoffii, Acinetobacter schindlerii, Pseudomonas poae and Shigella flexneri, only. In contrary to Rijavec et al. (2007) we did not isolate Panotea ananatis species.

This study shows more diverse EnB communities in leaves than described in steams of commercial cultivars maize by Johnston-Monje and Raizada (2011). Similar more various communities of bacterial endophytes in leaves than in stem and root segments were described in the case of medicinal herb Hygrophila spinosa (Pal and Paul, 2013). Among 46 identified species from 18 genera, 16 have been previously reported as maize endophytes, except for the genera Brachybacterium and Pedobacter. The genera Brachybacterium and Pedobacter have recently been described as endophytes in the leaves of young radish (Seo et al., 2010) and in Diapensa lapponica plants (Nissinen et al., 2012).

This study indicates the colonisation of different maize cultivars by noticeable various associations of EnB and important effect of local agro-environmental conditions. Higher diversity of EnB was found in plants collected from Kobierzyce, where we identified 35 species from 16 genera, than in plants from Smolice, where among 10 genera we identified 24 species. The most common phyla were $\gamma$-Proteobacteria and Actinobacteria, $40 \%$ and $26.4 \%$ of all isolates respectively, however there were $20.8 \%$ of isolates represented phylum Firmicutes, $8 \%$ represented phylum $\gamma$-Proteobacteria and $4.8 \%$ represented phylum Bacteroidetes as well. At the genus level, Pseudomonas (33.6\%), Bacillus (17.6\%), Arthrobacter (11.2\%) and Microbacterium (9.6\%) were dominant among them.

Among EnB isolates only strains identified as Ps. fluorescens were isolated from all tested six cultivars. Other most common species was $M$. testaceum, $B$. megaterium 
and Ar.nicotinovorans. Among isolated EnB six species only, Ps. clemancea, Ps. fluorescens, B. megaterium, B. simplex, Ar.nicotinovorans and Ar. itroguajacolicus, were found in aboveground parts of the same cultivar grown on both tested fields (Table III).

To the best of our knowledge, this study is the first to focus on the isolation and identification of endophytic bacteria of maize grown at temperate climate zone, sown from the same lots of seeds in two locations on different soils as well as grown in vitro using culturedependent method. Our research provides partial information about significant differentiations of associations of dominant cultivable EnB inhabiting different hybrid maize varieties.

Moreover, our studies based on species identification did not support the hypotheses that core associations of cultivable endophytic bacteria inhabiting maize tissues in temperate climate zone are cultivar dependent and are transmitted with the seeds from one generation to another. Nevertheless, each cultivar is inhabited by similar genera, but by different species. The fact that the same cultivars, sown from the same lots of seeds, under field conditions on two different locations were colonised with noticeably different associations of cultivable EnB suggest that cultivar specific metabolites are an important factor selecting endophytic bacteria from local agro-environment.

\section{Acknowledgements}

This work was supported by The National Science Center (NCN) no. 2011/01/N/NZ9/02332 for Katarzyna Pisarska.

\section{Literature}

Bodenhausen N., W.M. Horton and J. Bergelson. 2013. Bacterial communities associated with the leaves and the roots of Arabidopsis thaliana. PLOS ONE 8: e56329.

Chelius M.K. and E.W. Triplett. 2001. The diversity of archea and bacteria in associacion with roots of Zea mays L. Microb. Ecol. 41: 252-263.

Cho K.M., S.Y. Hong, S.M. Lee, Y.H. Kim, G.G. Kahng, Y.P. Lim, H. Kim and H.D. Yun. 2007. Endophytic bacterial communities in Ginseng and their antifungal activity against pathogens. FEMS Microbiol. Ecol. 54: 341-351.

Hallmann J., A. Quadt-Hallman, W.F. Mahaffee and J.W. Kloepper. 1997. Bacterial endophytes in agricultural crops. Can. J. Microbiol. 43: 895-914.

Hardoim P.R., L.S. van Ovebeek and J.D. van Elsas. 2008. Properties of bacterial endophytes and their role in plant growth. Trends Mircobiol. 16: 463-471.

Hoagland D.R. and D.I. Arnon. 1950. The water-culture method for growing plants without soil. California Agricultural Experiment Station Circular 347: 1-32.

Jacobs M.J., W.M. Bugbee and D.A. Gabrielson. 1985. Enumeration, location and characterization of endophytic bacteria within sugar beet roots. Can. J. Botany. 63: 1262-1265.

Johnston-Monje D. and M.N. Raizada. 2011. Conservation and diversity of seed associated endophytes in Zea across boundaries of evolution, ethnography and ecology. PLOS ONE 6: e20396.
Krawczyk K., J. Kamasa, A. Zwolinska. and H. Pospieszny. 2010. First report of Pantoea ananatis associated with leaf spot disease of maize in Poland. J. Plant Pathol. 92: 807-811.

Kuklinsky-Sorbal J., W.L. Araujo, R. Mendes, I.O. Geraldi, A.A. Pizzirani-Kleiner and J.L. Azevedo. 2004. Isolation and characterization of soybean - assocaited bacterial and their potential for plant growth promotion. Environ. Microbiol. 6: 1244-1251.

Liu Y., S. Zuo, L. Xu, Y. Zou and W. Song. 2012. Study on diversity of endophytic bacterial communities in seeds of hybrid maize and their parental lines. Arch. Microbiol. 194 (12): 1001-1012.

Liu Y., S. Zuo, Y. Zuo, J. Wang and W. Song. 2013. Investigation on diversity and population succession dynamics of endophytic bacteria from seed of maize (Zea mays L., Nongda108) at different growth stages. Ann. Microbiol. 63: 71-79.

Matsuoka Y., Y. Vigouroux, M.M. Goodman, G.J. Sanchez, E. Buckler and J. Doebley. 2002. A single domestication for maize shown by multilocus microsatellite genotyping. Proc. Natl. Acad. Sci. 99: 6080-6084.

McInroy J.A. and J.W. Kloepper. 1995. Survey of indigenous bacterial endophytes from cotton and sweet corn. Plant. Soil. 173: 337-342.

Nissinen R., M.K. Mannisto and J.D. van Elsas. 2012. Endophytic bacteria communities in three arctic plants from low arctic fell tundra are cold-adapted and host-plant specific. FEMS Microbiol. Ecol. 82: $510-522$.

Pal A. and A.K. Paul. 2013. Bacterial endophytes of the medicinal herb Hygrophila spinosa T. Anders and their antimicrobial activity. BJPR 3: 795-806.

Pérez-y-Terrón R., M.C. Villegas, A. Cuellar, J. Muñoz-Rojas, M. Castañeda-Lucio, I. Hernández-Lucas, R. Bustillos-Cristales, L. Bautista-Sosa, J.A. Munive, R. Caicedo-Rivas and others. 2009. Detection of Pantoea ananatis, causal agent of leaf spot disease of maize in Mexico. Australasian Plant Disease Notes 4: 96-99.

Rai R., P.K. Dash and B.M. Prasanna. 2007. Endophytic bacteral flora in the stem tissue of tropical maize (Zea mays L.) genotype: isolation, identyfication and enumeration. World J. Microbiol. Biotechnol. 23: 853-858.

Rijavec T., A. Lapanje, M. Dermastia and M. Rupnik. 2007 Isolation of bacterial endophytes from germinated maize kernels. Can. J. Microbiol. 53: 802-808.

Rodríguez Cáceres E.A. 1982. Improved medium for isolation of Azospirillum spp. Appl. Environ. Microbiol. 44: 990-991.

Segher D., L. Wittebolle, E.M. Top, W. Verstraete and S.D. Siciliano. 2004. Impact of agricultural practices on the Zea mays L. endophytic community. Appl. Environ. Microbiol. 70: 1475-1482.

Seo W.T., W.J. Lim, E.J. Kim, H.D. Yun, J. Han Lee and K.M. Cho. 2010. Endophytic bacterial diversity in the young radish and their antimicrobial activity against pathogens. J. Korean Soc. Appl. Biol. Chem. 53: 493-503.

Stanier R.Y., N.J. Palleroni and M. Doudoroff. 1966. The aerobic pseudomonads: a taxonomic study. J. Gen. Microbiol. 43: 159-171. Surette M.A., A.V. Sturz, R.R. Lada and J. Nowak. 2003. Bacterial endophytes in processing carrots (Daucus carota L. var. sativus): Their localization, population density, biodiversity and their effects on plant growth. Plant Soil 253: 381-390.

Xu M., J. Sheng, L. Chen, Y. Men, L. Gan, S. Guo and L. Shen. 2013. Bacterial community compositions of tomato (Lycopersicum esculentum Mill.) seeds and plant growth promoting activity of ACC deaminase producing Bacillus subtilis (HYT-12-1) on tomato seedlings. World J. Microbiol. Biotechnol. 30 (3): 835-845.

Zinniel D.K., P. Lambrecht, N.B. Harris, Z. Feng, D. Kuczmarski, P. Higley, C.A. Ishimaru, A. Arunakumari, R.G. Barletta and A.K. Vidaver. 2002. Isolation and characterization of endophytic colonizing bacteria from agronomic crops and prairie plants. Appl. Environ. Microbiol. 68: 2198-2208. 